\title{
Uji daya hambat minyak kelapa murni (virgin coconut oil) terhadap pertumbuhan bakteri Enterococcus faecalis
}

\author{
${ }^{1}$ Lisa K. Tumbel \\ ${ }^{2}$ Pemsi M. Wowor \\ ${ }^{3}$ Krista V. Siagian \\ ${ }^{1}$ Kandidat Skripsi Program Studi Pendidikan Dokter Gigi Fakultas Kedokteran \\ ${ }^{2}$ Bagian Farmakologi dan Terapi Fakultas Kedokteran \\ ${ }^{3}$ Program Studi Pendidikan Dokter Gigi Fakultas Kedokteran \\ Universitas Sam Ratulangi Manado \\ Email: Lisakristitumbel15@yahoo.com
}

\begin{abstract}
Generally, failures in root canal treatment are caused by the bacterium Enterococcus faecalis. Several studies using different types of herbs showed their inhibition effect on the growth of bacteria in the oral cavity. Coconut oil can be processed into pure coconut oil (virgin coconut oil, VCO) that contains lauric acid with its antibacterial effect. This study was aimed to determine the inhibitory effect of coconut oil on the growth of the bacteria Enterococcus faecalis. This was an experimental laboratory study with the post-test only control group design. We used a modified method of the Kirby-Bauer disk paper. Sample of VCO was made by using heating process. Enterococcus faecalis bacteria obtained directly from the patients' necrotic pulps were identified at the Pharmaceutical Microbiology Laboratory, University of Sam Ratulangi Manado. The results showed that Enterococcus faecalis bacteria were identified in the samples. The inhibition zone of VCO to Enterococcus faecalis was $10 \mathrm{~mm}$. Conclusion: Virgin coconut oil could inhibit the growth of Enterococcus faecalis.
\end{abstract}

Keywords: virgin coconut oil (Virgin coconut oil), Enterococcus faecalis, inhibition zone

\begin{abstract}
Abstrak: Pada perawatan saluran akar dapat ditemukan kegagalan perawatan yang disebabkan oleh bakteri Enterococcus faecalis. Terdapat beberapa penelitian mengenai berbagai jenis tumbuhan herbal yang telah dilakukan untuk menghambat pertumbuhan bakteri dalam rongga mulut, salah satunya yaitu tanaman kelapa yang dapat diolah menjadi minyak kelapa murni (virgin coconut oil, $\mathrm{VCO}$ ) yang mengandung senyawa aktif asam laurat dengan efek antibakteri. Penelitian ini bertujuan untuk mengetahui daya hambat VCO terhadap pertumbuhan bakteri Enterococcus faecalis. Jenis penelitian ialah eksperimental laboratorium dengan post-test only control group design. Metode pengujian menggunakan metode modifikasi Kirby-Bauer dengan paper disk. Sampel minyak kelapa murni dibuat sendiri dengan proses pemanasan. Bakteri Enterococcus faecalis diambil langsung dari pasien nekrosis pulpa lalu diidentifikasi di Laboratorium Mikrobiologi Farmasi FMIPA Universitas Sam Ratulangi Manado. Hasil penelitian menunjukkan adanya bakteri Enterococcus faecalis pada sampel hasil identifikasi. Dari hasil uji daya hambat didapatkan minyak kelapa murni (Virgin coconut oil) memiliki efek antibakteri dalam menghambat pertumbuhan Enterococcus faecalis dengan zona hambat sebesar $10 \mathrm{~mm}$. Simpulan: Virgin coconut oil dapat menghambat pertumbuhan bakteri Enterococcus faecalis.
\end{abstract}

Kata kunci: VCO, Enterococcus faecalis, zona hambat 
Perawatan saluran akar gigi atau dalam bidang kedokteran gigi dikenal dengan perawatan endodontik mempunyai tujuan yaitu untuk mempertahankan gigi di rongga mulut agar tetap dapat berfungsi dengan baik. Perawatan endodontik merupakan perawatan dengan mengangkat jaringan pulpa yang telah terinfeksi pada kamar pulpa dan saluran akar. ${ }^{1}$ Pada pasca perawatan endodontik diharapkan dapat mencapai keberhasilan.Namun seringkali, tidak dapat dihindari pada pasca perawatan endodontik juga dapat ditemukan kegagalan perawatan. Kegagalan ini terjadi akibat adanya bakteri penyebab infeksi pada gigi yang telah dilakukan perawatan. Bakteri penyebab infeksi tersebut ialah bakteri Enterococcus faecalis. ${ }^{2}$

Enterococcus faecalis merupakan bakteri komensal pada rongga mulut dengan jumlah kecil. Bakteri ini dapat menjadi patogen bila berada di saluran akar gigi. Bakteri ini bertanggung jawab terhadap $80-90 \%$ infeksi pada pasca perawatan saluran akar gigi. Enterococcus faecalis juga dapat menyebabkan infeksi paru, infeksi saluran urin, dan infeksi saluran cerna. Bakteri ini merupakan bakteri yang resisten terhadap bahan antibakteri seperti golongan penicillin. ${ }^{3}$

Dalam mengatasi kasus kegagalan pasca perawatan saluran akar yang disebabkan oleh bakteri Enterococcus faecalis diperlukan pengendalian mikroorganisme dengan cara menghambat bakteri tersebut dengan berbagai macam obat yang mengandung daya antibakteri. Dewasa ini banyak bahan-bahan kimia bersifat antibakteri yang tersedia untuk menghambat bakteri penyebab infeksi pasca perawatan saluran akar akan tetapi masih memiliki kelemahan antara lain dapat terjadi peradangan sehingga diharapkan adanya pengembangan obat antibakteri yang berasal dari bahan-bahan herbal yang memiliki kemampuan antibakteri yang sama dengan bahan-bahan non herbal. ${ }^{4}$

Indonesia kaya akan berbagai jenis tumbuh-tumbuhan yang banyak digunakan sebagai bahan herbal untuk pengobatan, salah satunya tumbuhan kelapa. Tumbuhan kelapa merupakan salah satu produk bahan alam yang hampir seluruh bagiannya dapat dimanfaatkan, ada yang diproduksi sebagai bahan makanan dan minuman, ada juga yang diproses menjadi minyak kelapa murni. Minyak kelapa murni atau Virgin coconut oil (VCO) adalah minyak kelapa asli yang dibuat dari bahan baku kelapa segar dan diproses dengan pemanasan terkendali dan tanpa bahan kimia. Hasil dari proses pemanasan, minyak kelapa dapat menghasilkan senyawa-senyawa esensial yang mengandung asam laurat, sehingga minyak kelapa murni mempunyai sifat antibakteri. ${ }^{5}$

Penelitian mengenai pemanfaatan VCO sebagai antibiotik dalam pengobatan infeksi saluran akar belum banyak dilaporkan. Penelitian ini bertujuan untuk mengetahui uji daya hambat VCO terhadap pertumbuhan bakteri Enterococcus faecalis.

\section{METODE PENELITIAN}

Jenis penelitian ini ialah eksperimental dengan menggunakan post test only control group design. Penelitian dilaksanakan di Laboratorium Farmasi Fakultas MIPA Universitas Sam Ratulangi, Manado pada bulan September 2016. Subjek penelitian ini ialah pertumbuhan bakteri Enterococcus faecalis. Variabel penelitian yaitu minyak kelapa murni atau Virgin coconut oil (VCO) dan bakteri enterococcus faecalis. Variabel kontrol pada kontrol positif ialah metronidazol dan kontrol negatif akuades.

Bahan dan media yang dipakai dalam penelitian ini ialah: minyak kelapa murni (diolah sendiri lalu diproses menjadi minyak dengan proses pemanasan diatas kompor), media transpor, media LB (digunakan sebagai media peremajaan untuk identifikasi bakteri), larutan baku McFarland 0,5 ekuivalen dengan suspensi sel bakteri dengan kosentrasi 1,5x108 $\mathrm{CFU} / \mathrm{ml}$ (sebagai standar kekeruhan suspensi bakteri uji), dan Muller Hinton agar (MHA).

Pertumbuhan bakteri Enterococcus faecalis yaitu zona hambat yang merupakan 
daerah zona bening yang terbentuk di sekitar kertas saring (paper disk), yang diukur diameter vertikal dan diameter horizontal dalam satuan millimeter $(\mathrm{mm})$ dengan menggunakan jangka sorong. Pengambilan sampel bakteri Enterococcus faecalis dilakukan saat pemeriksaan pada pasien yang sesuai kriteria sampel penelitian dan meminta persetujuan dari pasien untuk mengikuti prosedur penelitian.

Pengambilan sampel bakteri dilakukan pada gigi yang telah didiagnosis sebagai nekrosis pulpa, dengan cara menggunakan paper point steril yang dilakukan di tempat praktek dokter gigi dengan bantuan dari dokter gigi langsung. Sampel bakteri diidentifikasi di Laboratorium Farmasi MIPA Universitas Sam Ratulangi Manado.

Selanjutnya sampel bakteri dimasukkan ke tabung reaksi yang berisi media transpor, dicampurkan $\mathrm{NaCl}$ ke dalamnya sebanyak $10 \mathrm{ml}$ lalu disentrifugasi dan divortex kemudian dituangkan ke dalam 5 cawan Petri yang sudah terisi media LB, kemudian di inkubasi pada suhu $37^{\circ} \mathrm{C}$ selama 24 jam. Setelah masa inkubasi 24 jam, 5 cawan Petri tersebut dilakukan penggoresan, setelah itu diinkubasi lagi selama 24 jam pada suhu $37^{\circ} \mathrm{C}$. Media agar miring digunakan untuk inokulasi bakteri.

Sebelum bakteri ditanam pada media MHA, bagian belakang cawan Petri dibagi menjadi 3 bagian dengan menggunakan spidol. Bakteri yang sudah disuspensikan diambil dengan pipet tetes lalu dituangkan ke dalam cawan Petri lalu dioleskan secara merata pada media MHA. Langkah berikutnya yaitu paperdisk direndam dalam VCO selama 5 menit, lalu diletakkan dengan pinset pada 1 bagian cawan petri. Antibiotik metronidazol 0,5 gr yang sudah dihaluskan dan dilarutkan dengan akuades sebanyak $100 \mathrm{ml}$ direndam paper disk selama 5 menit lalu diletakkan pada 1 bagian sebagai kontrol positif, dan 1 bagian lainnya diletakkan paper disk yang diberikan akuades sebagai kontrol negatif.

Metode pengujian yang digunakan ialah metode modifikasi Kirby-Bauer dengan menggunakan paper disk. Analisis data hasil penelitian dihitung secara manual kemudian data dianalisis dengan menggunakan program komputer Microsoft excel serta disajikan dalam bentuk tabel, gambar, dan tulisan.

\section{HASIL PENELITIAN}

Cawan Petri yang sudah diinkubasi di dalam anaerobic jar diambil lalu dilihat zona hambatnya (Gambar 1). Diameter zona hambat diukur dengan jangka sorong, kemudian luas zona hambat dihitung dengan rumus dan dimasukkan pada tabel pengamatan.

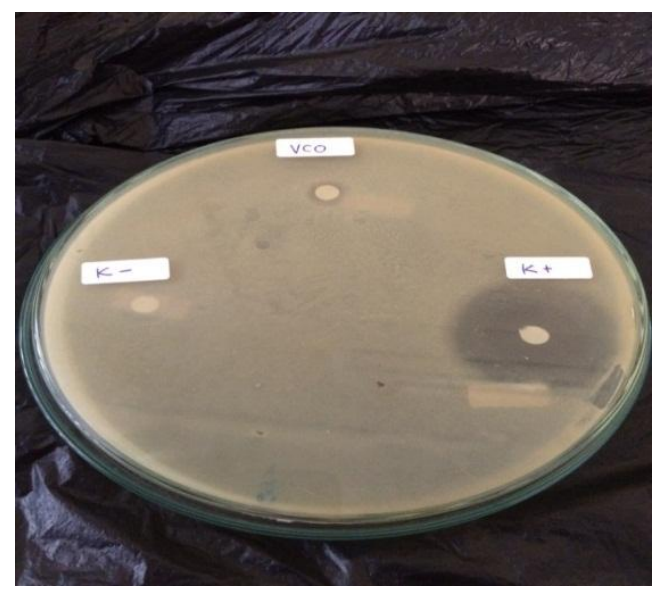

Gambar 1. Zona hambat yang terbentuk pada media MHA

Diameter zona hambat yang terbentuk pada media agar MHA dihitung nilai reratanya. Pada kelompok yang diberikan VCO didapatkan nilai rerata diameter zona hambat sebesar $10 \mathrm{~mm}$, sedangkan pada kelompok kontrol positif metronidazole didapatkan nilai rerata sebesar 38,3 m dan pada kelompok kontrol negatif didapatkan nilai yang konstan sebesar 0,00 $\mathrm{mm}$ (Tabel $1)$.

Tabel 1. Hasil pengukuran diameter zona hambat

\begin{tabular}{ccccc}
\hline Sampel & \multicolumn{3}{c}{$\begin{array}{c}\text { Diameter zona } \\
\text { hambat pada } \\
\text { cawan Petri }(\mathbf{m m})\end{array}$} & $\begin{array}{c}\text { Rerata } \\
(\mathbf{m m})\end{array}$ \\
\cline { 2 - 5 } & 1 & 2 & 3 & \\
\hline $\mathrm{VCO}$ & 7,5 & 11,5 & 11 & 10 \\
$\mathrm{~K}(+)$ & 35,5 & 38 & 41,5 & 38,3 \\
$\begin{array}{c}\text { metronidazole } \\
\text { K (-) } \\
\text { akuades }\end{array}$ & 0 & 0 & 0 & 0 \\
\hline
\end{tabular}




\section{BAHASAN}

Sampel bakteri diperoleh dari satu pasien penderita nekrosis pulpa yang disertai dengan abses dari tempat praktek dokter gigi. Sampel bakteri ini merupakan sampel bakteri yang telah diambil sebanyak 3 kali. Pada pengambilan sampel pertama dan kedua terjadi kesalahan sehingga dilakukan pengambilan sampel ke tiga. Sampel bakteri yang diperoleh dari penderita nekrosis pulpa yang disertai dengan abses dimasukkan dan dibagi dalam dua tabung reaksi yang sudah berisikan media transpor. Media transpor digunakan sebagai media pengambilan sampel untuk bakteri yang diambil langsung dari pasien ditempat praktek dokter gigi dan dibawa ke laboratorium mikrobiologi untuk identifikasi. Selain media transpor, juga terdapat media Luria Bertani (LB) yang digunakan sebagai media umum untuk pertumbuhan dasar bakteri karena kandungan yang terdapat pada media LB dapat memisahkan pertumbuhan dari beberapa koloni bakteri. Penggunaan media LB dimaksudkan karena bakteri yang diisolasi dari media transport ini belum diketahui jenisnya. Bila digunakan media yang spesifik dan selektif, dikhawatirkan hanya bakteri tertentu saja yang akan tumbuh.

Sampel isolasi bakteri pada media transpor yang telah dilarutkan dengan $\mathrm{NaCl}$ dituangkan ke media LB untuk memperbanyak pertumbuhan bakteri. Pertumbuhan bakteri ini ditandai oleh kekeruhan pada media. Kekeruhan media terlihat pada bagian atas yang menunjukan pertumbuhan bakteri aerob. Sampel bakteri yang telah dituangkan kedalam media LB dimurnikan kembali dengan 3 kali tahap pemurnian menggunakan media LB. Untuk pemurnian pertama, bakteri pada media LB yang sudah dioleskan sampel bakteri, dipindahkan pada media LB baru yang telah padat dengan cara menggoreskannya menggunakan jarum ose. Hasil pemurnian bakteri dari penggoresan pemurnian pertama akan membentuk beberapa koloni bakteri. Koloni bakteri tersebut kemudian dipindahkan pada media pemurnian kedua dengan cara masing-masing koloni bakteri dipindahkan pada media pemurnian yang baru. Hasil pemurnian kedua dipindahkan pada media pemurnian ketiga berupa media agar miring yang digunakan sebagai kultur stok dari kelima isolasi bakteri. Koloni yang terbentuk menunjukkan adanya pertumbuhan bakteri. Stok bakteri yang terbentuk dari media agar miring, masingmasing diidentifikasi dengan uji pewarnaan gram dilihat dengan mikroskop, uji fisiologis, dan uji biokimia. Setelah masing-masing sampel bakteri telah teridentifikasi, bakteri yang diperlukan dapat langsung digunakan untuk pengujian. Bila tidak langsung digunakan dapat disimpan pada lemari pendingin. Bakteri diregenerasi setiap dua minggu sekali dengan cara yang sama. ${ }^{6}$

Kelompok perlakuan VCO memiliki diameter zona hambat yang lebih kecil dibandingkan dengan kelompok kontrol positif metronidazol. Hal ini disebabkan karena VCO dan metronidazol memiliki mekanisme kerja dan kandungan jumlah senyawa kimia yang berbeda-beda. Selain itu minimal inhibitor concentration (MIC) untuk VCO belum diketahui, dan VCO yang dipakai pada penelitian ini merupakan hasil olahan sendiri sehingga kemungkinan memiliki senyawa asam laurat dengan jumlah senyawa yang kecil.

Pada penelitian ini metronidazol dipakai sebagai kontrol positif karena efektif untuk bakteri anaerob dan protozoa, yang sensitif terhadap beberapa organisme yang memiliki kemampuan untuk mengurangi bentuk aktif metronidazol di dalam selnya. Secara sistemik metronidazol digunakan untuk infeksi bakteri anaerob, amubiasis. Lambiasis. dan amubiasis hati. Gugus nitro pada metronidazol secara kimia sangat berperan untuk amubiasis karena mampu mereduksi dan berfungsi sebagai akseptor elektron terhadap gugus elektron donor protein amuba. Akibatnya terjadi gangguan proses biokimia dan interaksi terhadap DNA sehingga menyebabkan perubahan struktur helik DNA serta pemecahan ikatan dan kegagalan fungsi DNA yang berakibat 
kematian amuba. $^{7}$

Virgin coconut oil memiliki efek antibakteri yang berasal dari kandungan senyawa aktifnya. Virgin coconut oil mengandung asam lemak rantai menengah yang mekanisme kerjanya merusak dinding-dinding sel bakteri, mencairkan dan memperlihatkan efek membunuh virus dengan merusak DNA dan RNA virus yang dilapisi oleh lipida. $^{8}$ Asam lemak rantai menengah terdiri dari asam laurat, asam miristat, asam palmitat, asam kaprilat, dan asam kaprat. Dari beberapa asam lemak rantai menengah yang paling kuat efek menghambat pertumbuhan bakteri patogen yaitu asam laurat. Asam laurat merupakan asam lemak jenuh yang berantai menengah (medium chain fatty, MCFA) yang mudah dimetabolisme dan bersifat antimikroba sehingga dapat meningkatkan kekebalan tubuh.,10 Tabel 1 menunjukkan kategori respon zona hambat VCO termasuk dalam kategori sedang, metronidazole termasuk kategori sangat kuat dalam menghambat pertumbuhan bakteri Enterococcus faecalis sedangkan aquades tidak terdapat zona hambat. Hasil penelitian yang dilakukan Annisa $^{11}$ menunjukkan minyak kelapa murni (Virgin coconut oil) memiliki efek antibakteri terhadap bakteri Streptococcus mutans dengan rerata diameter zona hambat sebesar 11,65 mm. Penelitian ini juga menunjukkan VCO memiliki daya hambat terhadap bakteri Enterococcus faecalis dengan zona hambat sebesar 10 $\mathrm{mm}$.

\section{SIMPULAN}

Minyak kelapa murni (virgin coconut oil) memiliki daya hambat terhadap pertumbuhan bakteri Enterococcus faecalis dengan rerata zona hambat sebesar $10 \mathrm{~mm}$.

\section{SARAN}

1. Perlu dilakukan penelitian lebih lanjut mengenai efek antibakteri minyak kelapa murni (virgin coconut oil) terhadap pertumbuhan bakteri Enterococcus faecalis pada berbagai konsentrasi sehingga dapat diketahui minimal inhibitor concentration (MIC) minyak kelapa murni terhadap bakteri Enterococcus faecalis.

2. Perlu dilakukan penelitian lebih lanjut dengan mengukur jumlah kadar asam laurat pada minyak kelapa murni yang diolah sendiri dan yang diperoleh langsung dari pasar sehingga dapat dilihat hasil perbandingan keduanya dalam menghambat pertumbuhan bakteri Enterococcus faecalis.

3. Untuk penelitian selanjutnya, diharapkan minyak kelapa murni dapat diperoleh dengan formulasi yang tepat untuk dikembangkan menjadi obat terhadap bakteri Enterococcus faecalis yang dapat digunakan dalam bidang kedokteran gigi.

\section{DAFTAR PUSTAKA}

1. Walton RE, Torabinejad M. Prinsip dan Praktik Ilmu Endodonsia (3rd ed). Jakarta: EGC, 2003; p. 1-3.

2. Grossman LI, Oliet S, Del Rio CE. Ilmu Endodontik dalam Praktek (11th ed). Jakarta: EGC, 1995; p. 70-82.

3. Fisher K, Philips C. The Ecology, Epidemiology and Virulence of Enterococcus. Northampton: University of Northampton, 2009: p. 155.

4. Ariningrum R. Beberapa cara menjaga kebersihan gigi dan mulut. CDK. 2000;126:45-51.

5. Darmoyuwono W. Gaya Hidup Sehat dengan Virgin Coconut Oil (1st ed). Jakarta: Gramedia, 2006; p. 50-3.

6. Kusuma FD. Aktivitas antibakteri ekstrak etanol buah mengkudu terhadap bakteri pembusuk daging segar. Surakarta: Universitas Sebelas Maret; 2010.

7. Estuningtyas A, Setiawati A. Farmakologi dan Terapi (5th ed). Jakarta: Departemen Farmakologi dan Terapeutik FKUI, 2007; p. 552-3.

8. Antibakteri dan antivirus alami dalam minyak kelapa. Jakarta: Harian Analisa, 2011. Available from: http://aids-ina.org/modules.com/

9. Andi NA. Virgin Coconut Oil Minyak Penakluk Aneka Penyakit. Tanggerang: Agro Media Pustaka, 2005; p. 5.

10. Suhardiyono L. Tanaman Kelapa 
Tumbel, Wowor, Siagian: Uji daya hambat minyak kelapa murni (VCO) ...

Budidaya dan Pemanfaatannya. Yogyakarta: Kanisius,1998; p. 8.

11. Annisa RN. Efektivitas antimikroba berbagai jenis minyak nabati sebagai bahan tambahan pasta gigi terhadap bakteri Streptococcus mutans. Makasar: Universitas Hasanuddin; 2015. 